\title{
International Journal of Management and Sustainability
}

Vol. 3, No. 10, 615-623

$\operatorname{ISSN}(e): 2306-0662$

$\operatorname{ISSN}(p): 2306-9856$

DOI: $10.18488 /$ journal.11/2014.3.10/11.10.615.623

(C) 2014. Conscientia Beam. All Rights Reserved.

(D) Crossuark

\section{PERFORMANCE BASED BUDGETING SYSTEM DESIGN IN UNIVERSITAS SEBELAS MARET}

\author{
Santosa Tri Hananto ${ }^{1}$--- Lulus Kurniasih ${ }^{2}$--- Adi Firman Ramadhan ${ }^{3} \uparrow$ \\ ${ }^{1,2, s}$ Universitas Sebelas Maret, Solo, Indonesia
}

\begin{abstract}
Performance based budgeting requires information system in order to attain its goal. Universitas Sebelas Maret (UNS) has used the combination system of performance based budgeting and traditional budgeting. The objective of this research is to design application software that is useful for UNS in its budgeting process. This research analyzes system application of performance based budgeting. The system design consists of output design, document design, and input design. Output design of performance based budgeting consists of Planning Report, Financial Statement, and Performance Report. These reports supposed to be integrated. In document design, all files should be documented by the Development Plan Team. The final design is input design, which concern about planning and activities process.
\end{abstract}

Keywords: System design, Performance based budgeting, Budgeting process.

Received: 24 January 2015/ Revised: 24 February 2015/ Accepted: 26 February 2015/ Published: 28 February 2015

\section{Contribution/ Originality}

The paper contributes the first logical analysis about system of perfomance based budgeting in Indonesia's public university. Performance based budgeting has been demanded by the Goverment but there are little reasearch about it.

\section{INTRODUCTION}

Based on the results of research conducted Hananto and Kawan-kawan (2013) system of planning, budgeting, reporting, and accountability at the Universitas Sebelas Maret (UNS) have not been integrated, so the operational performance reports and financial statements have not been derived from a single unit integrated system. Integration of performance reporting and 
financial statements can provide convenience for UNS in the drafting process, reporting, and resource allocation. UNS information system is running well and supported with sufficient resources optimally, so the performance-based budgeting system automation is not difficult and possible to be impelemented.

It is necessary to build an information system to provide the information required in the performance-based budgeting process. Currently, UNS has implemented a budgeting system which is a combination of Performance-Based Budgeting system with traditional budgeting system (Hananto Santoso and Lulus, 2012). Therefore, the required design performance-based budgeting system which is no longer clash with the traditional budgeting system so that the objective performance-based budgeting can be achieved with either. Performance-based budgeting system design can be seen in figure 1 and 2 (Hananto and Kawan-kawan, 2013). Based on this background, in this study wanted to design automate the performance-based budgeting system at the UNS. This study will follow up on previous research that has resulted in the design of performance-based budgeting system. Application performance-based budgeting system software can be implemented with good hopes so as to provide adequate information.

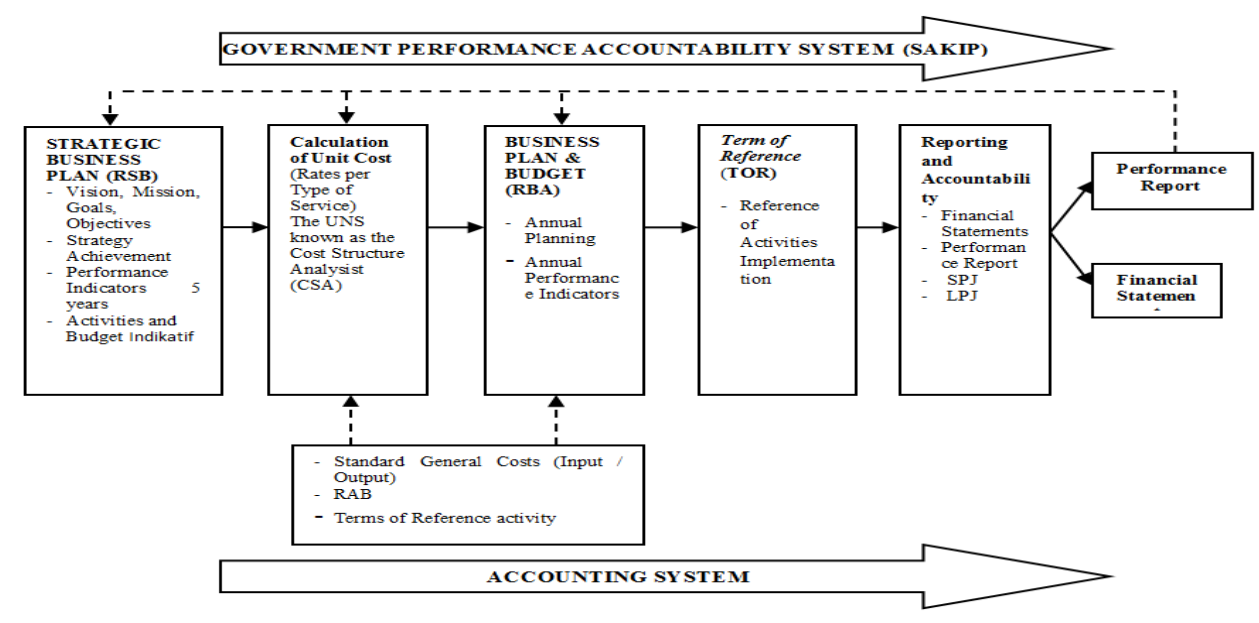

Figure-1. Proposed Performance-Based Budgeting Concept

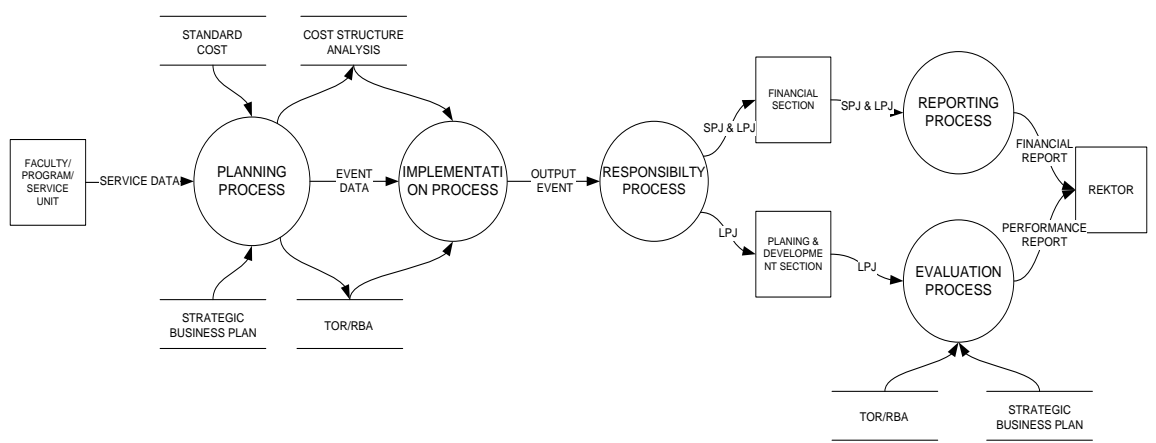

Figure-2. Proposed DFD of Performance Based Budgeting System 
This research aims is to make the application of performance-based budgeting system. If UNS has implemented a performance-based budgeting system application, Government Performance Accountability Report (LAKIP) can be generated automatically from the system.

Preparation of performance-based budgeting system applications include some of the following stages:
a. Output Design
b. File and Database Design
c. Input Design
d. Program Design
e. Procedures and Control Design

\section{LITERATURE REVIEW}

\subsection{Design and Development System}

Design of information systems can not be done without the stages clear and measurable. In the process of development of information systems, the approach that is often used is the System Development Life Cycle (SDLC), where there are four steps (Romney Marshal and Paul Steinbart, 2012):

1. Conceptual system design, in this stage the system developers create a common framework for the implementation of user needs and solving problems identified in the analysis process.

2. Physical Systems Design, which changed the design stage of conceptual design into product / design that can be directly implemented.

3. Implementation and conversion, the implementation phase of the system so that the known shortcomings and weaknesses sednag system developed.

4. Operation and maintenance, is the last stage in the design and development of systems.

Other approach to the development systems are prototyping, which is an approach to system development by using a model that is used as a prototype (Romney Marshal and Paul Steinbart, 2012). Steps in developing a system using prototyping (Romney Marshal and Paul Steinbart, 2012):

1. Specify basic needs, knowing the needs of users and the scope of the system which includes input, process and output.

2. Develop an initial prototype, in this stage protitipe developers build systems to be delivered to the user in order to get feedback from the user.

3. Modify the prototype to include additional requirements, based on feedback from the previous stages developers make improvements and ask for feedback from users on the improvements made.

4. Develop initial prototype into a fully functional system, the development of prototypes to be a system that will be used. 


\subsection{Prototyping}

Prototyping is a technique for building information systems quickly using rapid application development tool that has several advantages such as (Bentley Lonnie and Jeffrey Whitten, 2007):

1. Encourage and require the active participation of end-users

2. Iteration and change is a consequence of the development of the system (including change of thinking the end-user)

3. End-users do not know all the system needs to be implemented

4. Prototype is an active models so that end-users can view, hold, feel, and experience with the system.

5. The prototype that has been approved, the equivalent job specification paper design with one exception (error can be detected quickly)

6. Prototyping can enhance creativity because of the rapid feedback from users that can quickly deliver the right solution.

7. Prototyping can accelerate some of the phases in the life cycle, in this case prototyiping can combine several phases which are usually to be served one at a time.

In using prototyping as a technique to build the system, some things will be done:

\section{Output Design}

The output is an important component in information systems that run where the output can be classified into two characteristics: (1) the distribution and the user, and (2) methods of implementation (Bentley Lonnie and Jeffrey Whitten, 2007). Output design goal is to determine the nature, format, content, and timing of reporting, documents, and screen display (Romney Marshal and Paul Steinbart, 2012).

2. File and Database Design

Data from several units must be stored in a format that is compatible to help avoid problems, systems and incompatible formats, and the inability to communicate and share data to another unit (Romney Marshal and Paul Steinbart, 2012). Preparing technical design specifications for the data base in accordance with the needs and development (Bentley Lonnie and Jeffrey Whitten, 2007).

\section{Input Design}

Input design consists of two characteristics: (1) how the data is captured, entered, and processed and (2) methods and technologies used to capture the data and enter data (Bentley Lonnie and Jeffrey Whitten, 2007).

\section{Program Design}

Program design includes: (1) determine the needs of users, (2) create and document the floating plan, (3) make instruction program (computer code), (4) the trial program, (5) documenting programs, (6) user training programs, (7) to install the program, and (8) use and modify the program.

5. Procedures And Control Design 
The procedure includes the preparation of input, processing transactions, pendetekasian and error correction (error), pengendaian, balance reconciliation, database access, preparation and distribution of output, and the instructions for the computer operator. Control should be made to ensure the effectivity, efficency, and accuracy thus avoiding the occurrence of "garbage in, garbage out".

\section{RESEARCH METHOD}

The qualitative methods used in this study, more specifically descriptive analysis. According to (Sekaran and Bougie, 2010), descriptive study conducted to know and be able to explain the characteristics of the studied variable and situation. The purpose of descriptive study is to give researchers a history or to describe the aspects that are relevant to the phenomenon of attention from the perspective of a person, organization, industry orientation, or any other.

This study will focus on the stages of physical design system which includes (Romney Marshal and Paul Steinbart, 2012):

\section{Output Design}

This phase aims to establish a baseline, format, content, and timing of reports, documents, and display.

2. File and Database Design

This stage aims to design a data storage and data formats required

3. Input Design

Input design consider what data will be inputted and the optimal method of data input.

4. Program Design

Activity in the design of the program include: determining a user, create and document the development plan, write program instructions (computer code), testing programs, program documentation, and user training programs.

5. Procedures and Control Design

The procedure includes preparations of input, processing transactions, detection and error correction, control, balance reconciliation, database access, preparation and distribution of reports, and instructions for the computer operator. While the controls are built to ensure the effectiveness, efficiency, and accuracy of an information system.

\section{DISCUSSION}

\subsection{Output Design}

Design output performance based budgeting system consists of Planning Reports, Financial Statements and Performance Report.

\section{Planning Report}

Planning report contains summary of performance targets to be achieved each unit, including budgets, programs and key performance indicators (KPI) of each activity. With the planning 
report, the UNS can identify specific KPIs that have not been targeted by all units within the UNS. Also, it can be identified which is appropriate KPI targets, exceeding the target, or less than the target. The system can be produced in the form of planning output per unit of planning reports and aggregate UNS. As a warning signal system, each KPI planned not in accordance with the target in the Business Strategic Plan will automatically be given a red color. Thus before a budget is set, then the activities to be carried out must be in accordance with the target KPIs in Business Strategic Plan. In Planning Report each unit, there is an additional column for TOR and the RBA. This column is intended as a basis for verification of conformity with the RBA TOR. This is because often found any discrepancy between TOR and the RBA.

\section{Financial Statements}

UNS financial statements in accordance with the existing BLU system, whereby the resulting financial statements are the SAI and the GAAP financial statements, which consists of the Operational Reports, Budget Realization Report, Balance Sheet, Statement of Cash Flows.

\section{Performance Report}

Achievement of the performance report shows what has been planned compared with the realization. Performance report will integrated with the financial statements, so that the system can generate financial reports in addition, can also simultaneously generate performance reports as a basis for accountability and evaluation. Any activity that is not in accordance with the planned, systematically going straight red. There are two reports of performance, namely:

a. Performance Report / Evaluation Planning (CSA / RBA) to Realization

This is to reporting the realization that compared with the planning, so it will be seen whether the activities carried out are in accordance with the plan or not. In addition, it can also identify activities that may be carried out without prior planning.

b. Performance Report / Evaluation Strategic Planning Business with Actual

This report can be a reference whether the activities that have been carried out in accordance with the achievement of the Strategic Plan of business or not. This report can also be used as a basis for evaluating an urgent activities carried out without planning, whether these activities support the achievement of KPIs in Business Strategic Plan.

\subsection{File/Database Design}

File LPJ besides inputted and owned by the finance department, also must have a copy of which is filed by planning and development team. MySQL is used for database design in this application.

\subsection{Input Design}

The process of inputting can be classified as follows. 


\subsubsection{Planning Process}

In the planning process, each unit has been set CSA, making the RBA and TOR in accordance with the Business Strategic Plan. Planning and Development Teams are required to input Business Strategic Plan, RBA, and TOR of each unit. Thus it would appear fit between Business Strategic Plan, RBA, and TOR. Incompatibility can be directly evaluated by each unit. The inputs will systematically direct-recap into a single unit UNS. They can evaluate compliance the target in the Strategic Plan of the University Business. Before you set out, they must coordinating back with all the units if there is a mismatch.

\subsubsection{Implementation Process}

Once the project is implemented, each unit will make the SPJ and LPJ as the basis of accountability. Currently, SPJ inputted by the Finance Department for financial accountability. In our proposed system, the team must be given also a copy LPJ as lawyer-input basic KPIs that have been implemented. With a system that is integrated between the financial and performance, it can produce financial statements at the same time as performance reports.

\subsection{Program Design}

Use case diagrams drawn based on the analysis of design input and output.

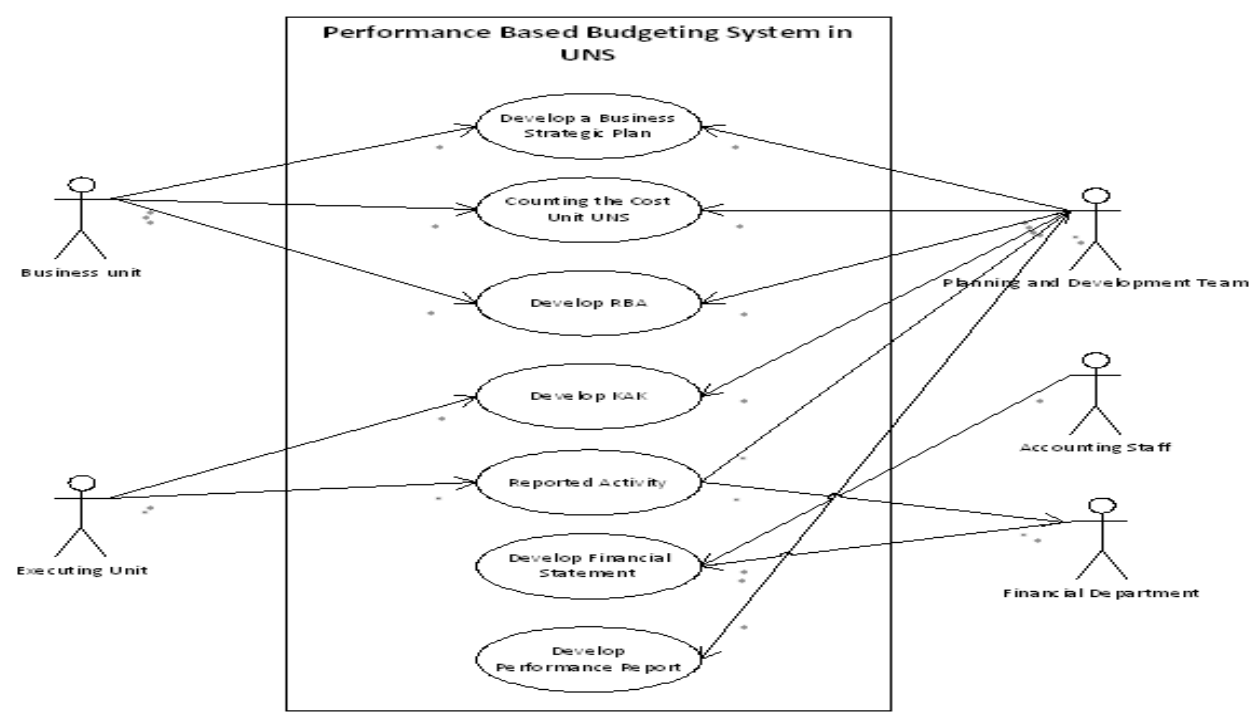

Figure-3. Use Case Diagram

From the picture above, use case diagram, we can see the relevant parties (actors) in the system is a business unit, Tim Renbang University / Faculty, Project Implementation Unit, Staff Accounting, Finance Department. Activities to be implemented in this system include: preparing a business plan (strategic plan), calculate the unit cost, arrange RBA, prepare TORs, prepare 
financial statements, and reports performance. Image display menu for performance-based budgeting system prototype can be seen in the figure 4 .

\subsection{Procedures and Control Design}

The following procedures in the performance-based budgeting system that starts from:

\subsubsection{Planning Stages}

Planning stages include: preparation of strategic business plan (Plan), the calculation of unit cost (cost structure analysis), preparation of business plans and budgets (RBA) yearly, and preparation of terms of reference (TOR). Parts involved in the planning stages include: Team Planning and Development Level University or Faculty and business units. Documents used in this phase of the Strategic Business Plan, RBA, and TOR.

\subsubsection{Stages of implementation}

This stages include of filing TOR, TOR verification, implementation and reporting of activities, and financial data entry and performance activities (KPI). The parts involved in this implementation stages are implementing unit activity, finance, and planning and development team. Documents used include: TOR, the financial statements of activities, and activity reports.

\subsubsection{Stages of Reporting and Accountability}

Reporting and accountability stages include the preparation of financial statements (quarterly, semester, and year) and the preparation of performance reports (quarterly, semester, and year). The parts involved in this stages include: accounting staff and team planning and development. Documents used in this stages are financial statements and reports performance.

\section{CONCLUSION}

The conclusions of the system analysis and design of performance-based budgeting system for the UNS are:

1. UNS has implemented a performance-based budgeting system, but the implementation is not entirely based on performance.

2. The performance of the resulting report can not provide information that is relevant and appropriate to the reality because using estimates for performance report and performance that is not reported because there is no clear mechanism related to performance reporting.

3. The design of performance-based budgeting system conducted by business unit, Tim Renbang University or Faculty, Unit implementing activities, Finance Department, and Accounting Staff. 
4. The activities in this performance-based budgeting system include: University strategic planning, preparation of unit cost, RBA drafting, TOR drafting, reporting activities, and the preparation of financial statements and performance reports.
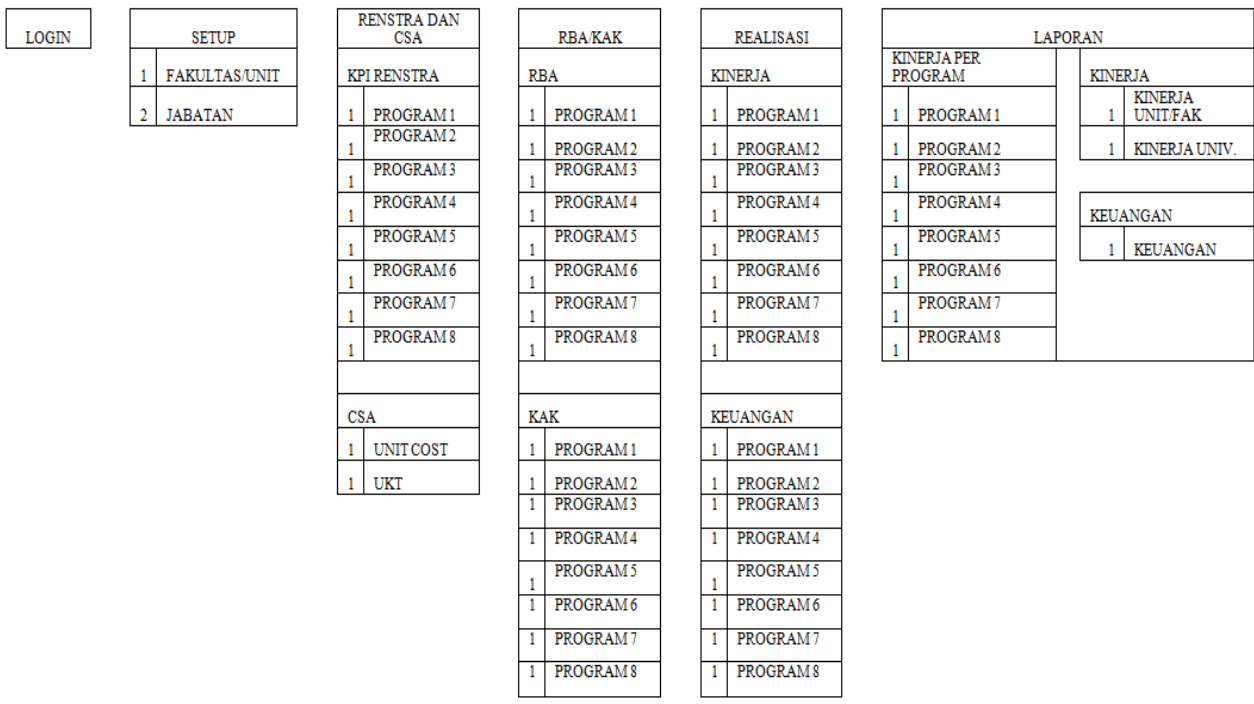

Figure-4. Menu Design of Prototype Software

Funding: This study received no specific financial support.

Competing Interests: The authors declare that they have no competing interests.

Contributors/Acknowledgement: All authors contributed equally to the conception and design of the study.

\section{REFERENCES}

Bentley Lonnie, D. and L. Jeffrey Whitten, 2007. System analysis and design for the global enterprise. New York: McGraw-Hill.

Hananto, S., Tri. and Kawan-kawan, 2013. Desain sistem penganggaran Berbasis Kinerja: Studi Kasus UNS. Research Report (Not Publish).

Hananto Santoso, T. and K. Lulus, 2012. Identifikasi Kebutuhan Penerapan Anggaran berbasis Kinerja: Studi kasus UNS. Research Report (Not Publish).

Romney Marshal, B. and J. Paul Steinbart, 2012. Accounting information system. USA: Pearson.

Sekaran, U. and R. Bougie, 2010. Research methods for business: A skill building approach. 5th Edn., New York: John Wiley \& Sons, Inc. 